\title{
PROSES KREATIF PENCIPTAAN BATIK MOTIF BAMBU KHAS KOTA MAGETAN DAN NGAWI
}

\author{
Riyanike Arista \\ Program Studi Seni Rupa Murni-FSRD \\ Universitas Sebelas Maret, Surakarta \\ riyanikearista144@gmail.com
}

\begin{abstract}
ABSTRAK
Batik Pring Sedapur yang berasal dari Desa Sidomukti, Kecamatan Plaosan, Kabupaten Magetan yang memiliki ciri khas ornamen bambu. Selain itu, di Desa Munggut, Kecamatan Padas, Kabupaten Ngawi juga memproduksi batik dengan motif bambu dengan kombinasi ornamen yang menjadi batik ciri khas kota Ngawi. Dari kemiripan objek tersebut terdorong untuk memahami latar belakang dan proses kreatif terciptanya Batik Pring Sedapur dan Batik Bambu. Penelitian menunjukkan bahwa Batik Pring Sedapur diciptakan oleh Kepala Desa Sidomukti yang bernama Bapak Tikno. Motif ini terinspirasi dari keadaan desa yang masih banyak ditumbuhi oleh pohon-pohon bambu yang terletak di Dusun Papringan. Sedangkan, batik dengan motif bambu di Ngawi dipelopori oleh Bu Siwi yang motifnya terinspirasi dari sejarah kota Ngawi yang berasal dari kata $N g$ dan Awi yang berarti bambu. Batik Pring Sedapur dan Batik Bambu memiliki kesamaan proses kreatif dalam penciptaannya yang berasal dari dorongan eksternal yaitu flora di lingkungan sekitar.
\end{abstract}

Kata kunci: batik, bambu, proses kreatif, Magetan, Ngawi

\section{ABSTRACT}

Pring Sedapur batik coming from Sidomukti village, Plaosan sub-district, Magetan district has the typical characteristic of bamboo ornament. Moreover in Munggut village, Padas subdistrict, Ngawi district, people also produce batik with bamboo motif plus the combination of ornaments that becomes the typical batik of Ngawi city. Based on this similarity in object, the writer wants to comprehend the background and creative process of creating Pring Sedapur batik and Bamboo batik. Research shows that Pring Sedapur batik is created by the head of Sidomukti village that is Mr. Tikno. This motif is inspired from the condition of this village that's still full of bamboo trees particularly in Papringan area. Whereas Bamboo batik in Ngawi is pioneered by Mrs. Siwi, and bamboo motif in this batik is inspired from the history of Ngawi city. The name of Ngawi comes from the words "Ng" and "Awi" that means bamboo. Pring Sedapur batik and Bamboo batik have a similarity in the creative process of their creation coming from an external urge namely the flora of surrounding environment.

Keywords: Batik, bamboo, creative process, Magetan, Ngawi. 


\section{Riyanike Arista}

\section{PENDAHULUAN}

Batik merupakan sebuah wujud kebudayaan yang tergolong dalam warisan seni rupa tradisi di Indonesia. Budaya asli Indonesia memiliki batik yang menjadi salah satu ikonnya. Hal ini juga diperkuat dengan ditetapkannya batik oleh UNESCO sebagai Warisan Kemanusiaan untuk Budaya Lisan dan Non-Bendawi (Masterpieces of the Oral and Intangible Heritage of Humanity) pada tanggal 2 Oktober 2009. Sejak itulah, 2 Oktober diperingati sebagai "Hari Batik Nasional" (Wulandari, 2011: 7). $\quad$ Seiring perkembangannya, hampir seluruh daerah mengembangkan potensi batik yang mereka miliki. Seperti batik Solo, Jogja, Pekalongan, Cirebon, Tuban, Lasem, Magetan, Ngawi, Lumajang, Banyuwangi, dan sebagainya. Beberapa daerah dikenal menjadi sentra industri batik, walaupun beberapa daerah masih dalam proses menggali potensi batiknya sebagai ciri khas daerah mereka serta dengan menciptakan motif yang berbeda pula. Potensi ini menjadi kekuatan di sektor industri kreatif jika digarap dengan serius.

Pada awal keberadaannya, motif batik terbentuk dari simbol-simbol yang bermakna dan bernuansa tradisional Jawa, Islami, Hinduisme (misalnya pada motif kawung) dan bernuansa Budhisme. Saat ini bentuk dan corak memiliki kemungkinan gagasan yang tidak terbatas, bersifat dekoratif sekuler ketimbang simbolis spiritual, serta amat dinamis siklus-siklus pergantiannya yang dapat disejajarkan dengan kain modern yang lainnya (Musman, dkk: 2011). Batik Pring Sedapur berasal dari Desa Sidomukti, Kecamatan Plaosan, Kabupaten Magetan. Secara geografis, Kabupaten Magetan berbatasan langsung dengan propinsi Jawa Tengah, oleh karena itu, budaya daerah Kabupaten Magetan mirip dengan budaya Jawa Tengah. Namun dalam hal membuat batik memiliki ciri yang berbeda dengan batik Jawa Tengah pada umumnya. Batik Magetan memiliki ciri khas yaitu ornamen bambu. Motif tersebut masih diproduksi oleh para pengrajin batik yang ada di Desa Sidomukti. Seiring perkembangan zaman, selain motif utama yaitu bambu, batik Pring Sedapur dikombinasikan dengan beberapa ornamen. Selain batik bambu yang ada di Magetan, ternyata Ngawi juga mempunyai ciri khas motif batik bambu dengan kombinasi ornamen. Sentra batik ini terletak di Desa Munggut, Kecamatan Padas, Kabupaten Ngawi.

Berbicara mengenai seni tidak lepas dari estetika dan proses penciptaan yang bertahap. Penciptaan merupakan suatu proses yang timbul karena adanya dorongan dari diri seniman. Dorongan tersebut datang karena adanya pengaruh dari luar maupun dari dalam. Contoh pengaruh dorongan dari luar adalah penciptaan yang terinspirasi dari 


\section{Riyanike Arista}

alam, peristiwa dalam kehidupan seharihari manusia, maupun aktivitas kehidupan hewan, latar belakang, baik kebudayaan, sosial, ekonomi dan pendidikan yang pernah dilihat, didengar dan dirasakan seniman atau dapat disebut sebagai pengalaman inderawi yang dialami oleh seniman. Jika dorongan itu datangnya dari dalam atau dorongan yang bersifat rohani yaitu kebutuhan-kebutuhan yang dirasakan oleh rohaninya secara mendalam, bahkan mungkin tak disadari. Penciptaan sama halnya dengan proses kreatif terbentuknya sebuah produk seni. Proses kreatif adalah dorongan awal hingga sebuah karya seni itu selesai (Prawira: 2003: 88-93).

Seniman dan desainer menciptakan motif batik untuk menyalurkan kreativitasnya. Melalui makna dan simbolis motif batik, dapat memberikan pesan dan kesan kepada penikmat, karena setiap motif batik memiliki makna tersendiri. Makna tersebut menunjukkan kedalaman pemahaman terhadap nilai-nilai lokal, hingga sekarang nilai-nilai tersebut masih bertahan. Pada konteks kreativitas sejarah menunjukkan bahwa sektor produksi batik mengalami perkembangan dalam proses kreativitasnya. Hal ini tumbuh dari kreativitas sektor produksi batik dalam menanggapi aspirasi sektor konsumsi atau pasar (Musman, 2011: 121-122).

Proses kreatif batik Pring Sedapur di Magetan dan Batik Ngawi menjadi daya tarik penulis karena ide penciptaan samasama menggunakan motif bambu sebagai objek batik yang menjadi ciri khas kedua kota tersebut. Batik Pring Sedapur dan Batik Ngawi diciptakan dengan motif yang berbeda-beda oleh seniman dan desainer. Sedangkan gagasan awal dan pra-desain harus mengidentifikasi masalah atau latar belakang penciptaan suatu motif. Perbedaan gagasan awal penciptaan atau proses kreatif dalam perkembangan kedua batik bambu inilah yang perlu dikaji oleh peneliti. Berdasarkan latar belakang permasalahan tersebut, tujuan dari penelitian ini adalah mendeskripsikan proses kreatif dan penciptaan motif bambu sebagai ide kreativitas penciptaan batik yang menjadi ciri khas kota Magetan dan Ngawi. Hasil penelitian ini diharapkan bermanfaat untuk menambah pengetahuan baru mengenai objek bambu sebagai motif batik kota Magetan dan Ngawi.

Berdasarkan masalah yang diajukan dalam penelitian ini lebih menekankan pada proses kreatif perancang motif batik Pring Sedapur dan batik Ngawi, maka pendekatan yang dipilih adalah pendekatan deskriptif kualitatif. Metode yang dilakukan menggunakan metode observasi, wawancara, dan dokumen. Selanjutnya data dianalisis melalui tahap reduksi data, sajian data dan verifikasi data.

Analisis yang digunakan adalah analisis antar kasus. Jenis penelitian ini 


\section{Riyanike Arista}

tidak hanya dilakukan di satu lokasi, tetapi di beberapa lokasi dengan karakteristiknya yang berbeda yang memungkinkan terjadinya perbedaan hasil (Soetopo, 2002: 94-104). Dalam penafsiran data dilakukan dengan cara analisis komparatif yakni dengan jalan membandingkan apakah fakta dari kedua lokasi tersebut memiliki kesamaan atau perbedaan (Moleong, 2002: 207-213). Dalam penelitian ini, dapat dibandingkan proses kreatif yang dilakukan antara pencipta Batik Pring Sedapur di Magetan dengan Batik Bambu di Ngawi.

\section{PEMBAHASAN}

\section{Batik Magetan dan Ngawi}

Secara geografis, Kabupaten Magetan berbatasan dengan Kabupaten Ngawi di sebelah utara, Kota Madiun dan Kabupaten Madiun di sebelah timur. Kabupaten Ponorogo, serta Kabupaten Karanganyar dan Kabupaten Wonogiri keduanya termasuk propinsi Jawa Tengah. Tidak lain halnya dengan budayanya. Magetan memiliki budaya daerah yang sangat mirip dengan budaya Jawa Tengah. Namun, dalam hal membuat batik, ternyata Magetan memiliki ciri khas batik yang sama sekali berbeda dengan ciri batik secara umum dari Jawa Tengah.

Ornamen yang digunakan dalam motif batiknya adalah bambu, atau lebih tepatnya rumpun bambu yang digambar secara spesifik. Pring Sedapur adalah nama motif batik yang digunakan di banyak daerah, namun tampilan desain Pring Sedapur Magetan sama sekali berbeda (lihat gambar 1 dan 2). Secara umum motif Pring Sedapur menggambarkan rumpun bambu dan sepasang burung yang bertengger di atasnya (Anshori, 2011: 177).

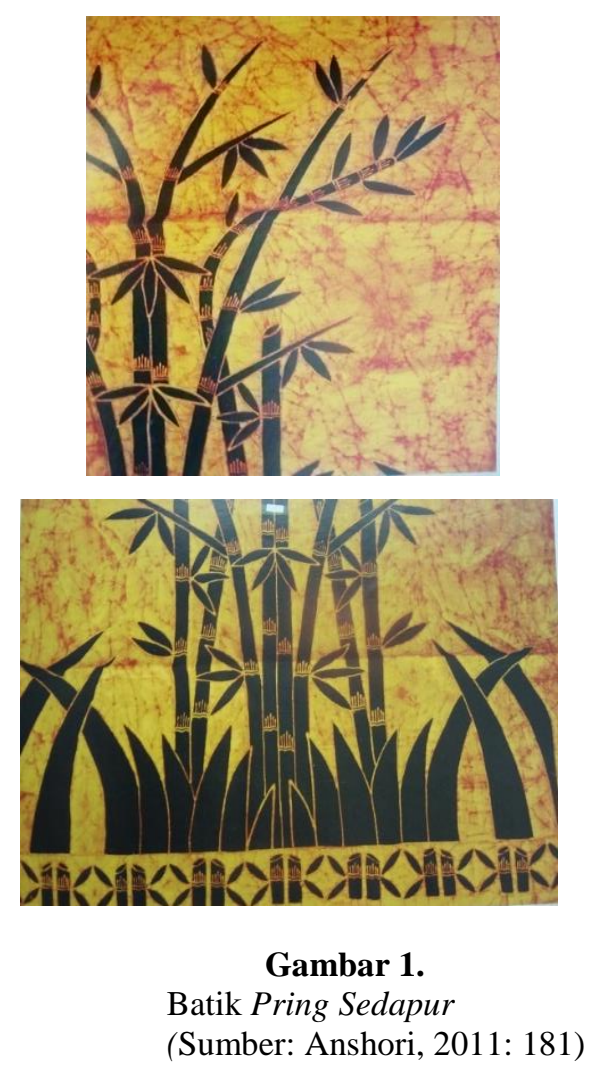

Sedangkan secara geografis, Kabupaten Ngawi berbatasan langsung dengan Kabupaten Magetan dan Kabupaten Madiun di sebelah selatan, Kabupaten Sragen dan Kabupaten Karanganyar di sebelah barat, berbatasan langsung dengan Grobogan, Blora, dan Kabupaten Bojonegoro disebelah utara, dan berbatasan dengan Kabupaten Madiun di sebelah Timur. Untuk melestarikan budayanya, Ngawi mempunyai industri yang sedang 


\section{Riyanike Arista}

dikembangkan yaitu industri batik. Saat ini ada dua sentra industri batik di Ngawi yang terdapat di Desa Banyubiru, Kecamatan Widodaren dan di Desa Munggut, Kecamatan Padas. Sama halnya dengan Magetan, batik Ngawi juga bermotifkan bambu. Batik Bambu mempunyai warna yang disesuaikan dengan permintaan konsumen dan permintaan pasar. Selain motif bambu, motif batik ngawi juga dipadu padankan dengan objek lainnya seperti manusia purba, melon, jati, kedelai, padi, daun teh, dan masih banyak lagi motif lainnya. Batik Ngawi juga diaplikasikan pada baju dan seragam sekolah (Bappeda Jatim prov).

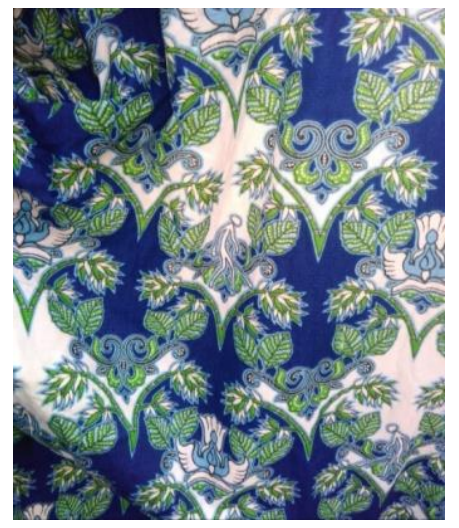

Gambar 3.

Motif Batik Bambu Ngawi

(Dok. Riyanike Arista, 2017)

\section{Proses Kreatif}

Proses kreatif tidak lepas dari kreativitas. Kreativitas dimulai dari melihat. Atau dapat dikatakan kemampuan kreatif sering dihubungkan dengan tindakan melihat dan dalam pikiran kita timbul bermacam tafsiran. Lalu dalam penafsiran, muncul ide-ide yang khas pula. Secara keseluruhan, kreativitas dalam seni bertujuan untuk mencari nilai makna.

Pola proses kreatif menurut Monroe secara garis besar dapat dibagi atas beberapa kelompok, antara lain:

1. Adanya karakteristik yang sama pada setiap seni apapun medianya, gejala ini tampak karena hampir setiap karya seni selalu menggunakan topik utama. Pendekatan pola kreatif terutama karya-karyanya mempunyai hasil akhir akibat proses kreatif yang sama pula.

2. Adanya analogi pengalaman estetis: gejala ini terbukti karena adanya apresiasi dan penghargaan untuk di nilai. Ada pula pola kreativitas yang dapat dipergunakan untuk mencapai hal lain.

3. Adanya analogi antara satu kegiatan kreatif dengan kegiatan kreatif lainnya. Hal ini diungkapkan secara klasik oleh Dewey dengan mencoba mengadakan penelitian bagaimana sebenarnya manusia berpikir. Ada sumber utama yang dapat dikaji, terutama dengan pengalaman presepsi kreatif. Ketiga sumber tersebut adalah seniman, ahli psikologi atau filsafat (Prawira, 2003: 90).

Desoir membagi proses kreasi dalam empat tahap, yaitu: 
a. Kondisi awal seniman yang secara samar-samar mengalami pencerahan

b. Tahap kejelasan konsepsi

c. Perwujudan konsep dalam sketsa

d. Penyelesaian karya

Sifat sebenarnya dari kontrol seniman terhadap proses kreatif bermaksud menghindarkan semua yang akan melihat karya hanya pada satu faktor saja, baik pada waktu sedang digarap ataupun pada akhirnya. Kontrol tersebut sebenarnya bersifat internal terhadap proses itu sendiri, dan bahwa masing proses membangkitkan arah serta momentumnya sendiri. Ada tiga pokok yang berkaitan dengan proses kreatif yaitu insep, perkembangan, dan penyelesaian hasil karya. Insep yang mendominasi sebuah proses kreatif. Insep adalah mungkin sekali suatu macam barang atau apa saja, kata-kata kalimat pertama dari suatu cerita, plot sederhana dari situasi, goresan kuas, tema, figure, nada ataupun gaya. Seniman dalam menciptakan suatu karya mempunyai ide yang ada dipikiran dan seniman menciptakan ide tersebut menjadi suatu objek karya. Jika seniman menilai objek karya lebih jelek daripada ide yang dipikirkan di awal, maka seniman tersebut harus mengulangi karyanya dari awal. Jika dalam setiap usaha untuk memperbaikinya selalu gagal, maka seluruh proyek akan dibiarkan tetap tidak selesai, karena memang tidak dapat terselesaikan. Pada tahap penyelesaian sebuah karya, seniman mengetahui kapan karyanya telah selesai yaitu ketika karya itu telah cukup atas usaha yang dilakukannya (Setjoatmodjo, 1988: 41-47).

Karya seni lahir karena adanya seniman yang menghadirkan karya tersebut. Penghadiran karya seni ini dapat disebut sebagai representasi. Disebut demikian karena memang dalam proses seniman bersinggungan dengan kenyataan objektif di luar dirinya atau kenyataan objektif di luar dirinya atau kenyataan dalam dirinya sendiri. Tanggapan ini dimiliki oleh seniman dan diungkapkan, dipresentasikan ke luar dirinya. Maka, lahirlah karya seni. Karena karya seni mencangkup dua aspek, yakni nilai intrinsik dan nilai ekstrinsik seni, maka dari segi kreativitas dalam seni harus ditinjau dari dua sudut tersebut. Pada dasarnya setiap seniman adalah juga seorang intelektual dalam tingkat apapun, karena setiap seniman mencipta berdasarkan tanggapannya terhadap lingkungan budaya maupun lingkungan faktual. Setiap seniman mencipta bukan sekedar memenuhi hasrat estetikanya belaka, tetapi karena didorong oleh lahirnya berbagai kejanggalan dalam hidup lingkungannya. Karya seni merupakan usaha untuk menjawab atau menanggapi kejanggalan hidup zamannya. Jadi, titik tolak kreativitas adalah justru hal-hal yang 


\section{Riyanike Arista}

sifatnya ekstrinsik seni. Persoalan ekstrinsik seni dicoba dijawab dengan ucapan otonomi seni, yakni aspek instrinsik seni.

Seniman yang menyatu dengan masyarakat akan belajar dari tradisi masa kini, yaitu karya-karya terpilih yang sesuai dengan pemikiran masa kini yang diambil dari kekayaan tradisi atau warisan seninya. Seniman menciptakan karya seninya berdasarkan nilai-nilai yang dijunjung tinggi oleh masyarakatnya. Begitulah kita lihat bahwa setiap karya seni atau seniman mula-mula dibentuk oleh tradisi. Setiap calon seniman yang tidak mengenal apa yang disebut lama dalam tradisi. Sejarah seni adalah paduan mutlak untuk dapat mengenal tradisi seni. Berbagai warisan karya seni masyarakat dapat dinilai dari generasi sekarang dalam menghargainya. (Sumardjo, 2000: 76- 91).

\section{Psikologi Seni}

Psikologi seni adalah salah satu pendekatan yang membantu memberikan jawaban atas pertanyaan-pertanyaan yang menyangkut seniman, seperti artistik, proses kreasi, faktor pribadi dalam seni. Selain itu, juga membantu memahami pengalaman estetik pengalaman seni bagi publik atau apresiator. Dengan kata lain psikologi seni adalah bagian dari ilmu psikologi yang memfokuskan diri pada pertanyaan-pertanyaan yang berkaian dengan para pendukung dalam proses artistik, yaitu seniman, pengamat, dan kritikus. Seorang psikolog seni terutama tertarik pada pada proses-proses psikologis yang memungkinkan penciptaan dan tanggapan-tanggapan seni. Berikut adalah kerangka berpikir dalam psikologi seni:

\begin{tabular}{|l|l|l|}
\hline & Seniman & Pengamat \\
\hline Motivasi: “mengapa" & $\begin{array}{l}\text { Apa yang mendorong } \\
\text { seniman untuk mencipta? }\end{array}$ & $\begin{array}{l}\text { Apa yang mendorong } \\
\text { manusia } \\
\text { untuk }\end{array}$ \\
\hline $\begin{array}{l}\text { Kognisi } \\
\text { "bagaimana"resiasi karya seni? }\end{array}$ & $\begin{array}{l}\text { Proses kognitif apa yang } \\
\text { terlibat dalam kreasi artistik? }\end{array}$ & $\begin{array}{l}\text { Kemampuan kognitif apa } \\
\text { yang dibutuhkan untuk } \\
\text { memahami karya seni? }\end{array}$ \\
\hline
\end{tabular}

\section{Tabel 1.}

Kerangka berpikir psikologi seni

(Sumber : Irma Damajanti, 2006: 15-16)

Aristoteles mengajukan

pandangan mengenai kreasi artistik, yang ditekankan pada keterlibatan, keahlian yang terkendali, cermat, dan penuh ketelitian.
Plato memandang kreasi artistik memiliki sumber eksternal, inspirasi yang bersifat ketuhanan, sedangkan kaum Romantik mempercayai bahwa kreasi artistik berasal 


\section{Riyanike Arista}

dari sumber internal, aspek ketidaksadaran.

Orang Yunani percaya pada inspirasi yang berasal dari atas (above), sedangkan para seniman abad ke-19 percaya pada inspirasi yang berasal dari bawah (below) (Damajanti, 2006: 13-17).

\section{Latar Belakang Terciptanya Batik Pring Sedapur}

Batik Sidomukti sempat menghilang beberapa dekade dan muncul lagi pada tahun 70-an dengan motif asli mirip dengan motif Batik Mojokerto. Namun, pada akhir tahun 70-an batik Sidomukti kembali menghilang. Hal ini dikarenakan sulitnya pemasaran pada masa itu. Pada tahun 2000, Tikno menjabat sebagai kepala desa di Desa Sidomukti, beliau melihat keadaan ekonomi warganya yang memprihatinkan. Mata pencaharian mereka hanya mengandalkan di sektor pertanian. Itupun hanya penduduk laki-laki, perempuannya hanya menjadi ibu rumah tangga dan tidak mempunyai penghasilan. Walaupun terkadang membantu pekerjaan di sawah. Padahal di sisi lain,hasil pertanian masih dipanen beberapa bulan berikutnya. Otomatis selama mereka menunggu tidak mempunyai penghasilan. Melihat keadaaan ini, Tikno mempunyai ide untuk memperkenalkan batik kembali kepada ibuibu di Desa Sidomukti.

Pada awalnya, batik yang dibuat bercorak klasik dengan corak yang umum dipasaran. Pada saat itu, sulit memasarkan batik jenis tersebut karena kalah saing dengan batik Solo dan batik Jogja. Pada tahun 2004, terciptalah motif batik baru yaitu motif batik bambu yang disebut dengan Batik Pring Sedapur. Pada saat ini, terdapat 3 tempat pembuatan batik di Desa Sidomukti. Yaitu di Dusun Papringan, di Kantor Desa, dan Wisma Bati di rumah Tikno.

\section{Proses Kreatif Batik Pring Sedapur}

Batik Pring Sedapur merupakan batik yang menjadi ciri khas kota Magetan. Yang pertama kali menciptakan batik tersebut adalah Tikno. Tikno menamakan Batik Pring Sedapur bermula pada awal penciptaannya yang berada di Dusun Papringan, Desa Sidomukti. Di Papringan banyak ditumbuhi pohon bambu yang menggerombol. Batik Pring Sidomukti dikombinasikan dengan motif garuda, cucak rowo, bunga-bunga, naga, binatang, dan tumbuhan-tumbuhan yang banyak tumbuh di sekitar Gunung Lawu. Dalam proses membatik, harus mempunyai ide dan konsep sebelum ke tahap yang utama yaitu tahap penchantingan. Setiap orang yang berkarya seni selalu menjalani tahap proses kreatif. Tahap-tahap dari proses kreatif di Batik Sidomukti sama seperti pendapat Desoir, yaitu: 


\section{Riyanike Arista}

1. Kondisi awal seniman yang secara samar-samar mengalami pencerahan.

Dalam kondisi ini, Tikno tergantung pada perasaan dan tingkat emosional dalam diri beliau. Yaitu mempunyai kemauan atau tidak dalam mengerjakan atau menciptakan motif batik Pring Sedapur berbeda dari batik yang sebelumnya. Sebelum mendapatkan ide untuk membuat, biasanya beliau jalan-jalan keliling desa. Di Desa banyak tumbuh-tumbuhan yang dapat menginspirasi beliau dalam menemukan sebuah ide dalam motif batik dengan tidak mengubah tumbuhan pring sebagai ciri khas batik di Desa Sidomukti. Selain itu, pemandangan di Gunung Lawu juga menarik, menyegarkan mata serta pikiran untuk mendapatkan sebuah pencerahan.

\section{Tahap kejelasan konsepsi.}

Dalam tahap ini, Tikno memadupadankan dan merangkai antara gambar bambu sebagai ornamen utama dan bunga atau dedaunan sebagai ornamen tambahan sesuai dengan komposisi. Jika ada pemesan yang menghendaki adanya logo, harus dijadikan sebagai point of interest di antara motif secara keseluruhan.

\section{Perwujudan konsep dalam sketsa}

Ide yang sudah terpikirkan sebelumnya, diaplikasikan di kertas. Tikno menggunakan media kertas roti untuk membuat sketsa (lihat gambar 4 dan 5). Ini bertujuan agar mudah di blat pada tahap selanjutnya.

4. Penyelesaian karya.

Dari tahap sketsa, dilanjutkan pada tahap blat di kain dan di atas meja kaca Hal| 133 yang terdapat lampu dari bawah meja. Selanjutnya kain batik tersebut di canting sesuai gambar. Setelah di canting, batik diwarnai (lihat gambar 6) sesuai dengan konsep awal. Setelah itu dijemur dan direbus dan dicelupkan pada kimia. Selanjutnya batik dicuci di sungai yang terdapat di Desa Sidomukti. Hal ini merupakan kebiasaan yang masih dijalankan sejak batik Pring Sedapur diciptakan. Tahap selanjutnya adalah pengeringan dan menjadi kain batik jadi (lihat gambar 7).
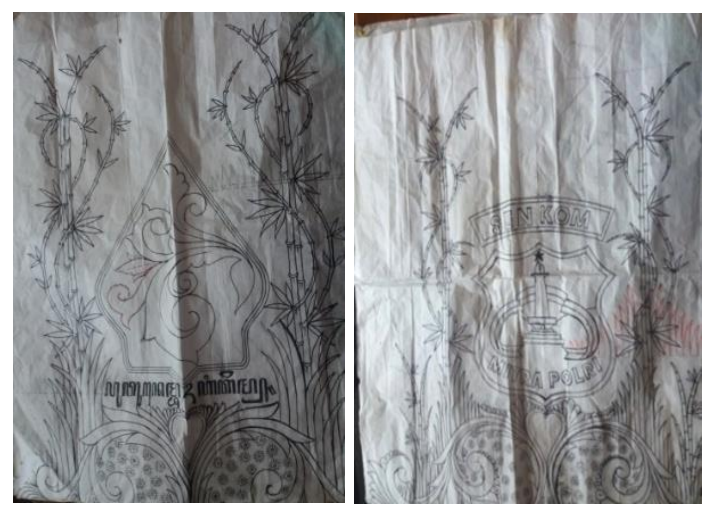

Gambar 4 dan 5.

Sketsa Batik Pring Sedapur (Dok. Riyanike Arista, 2016) 


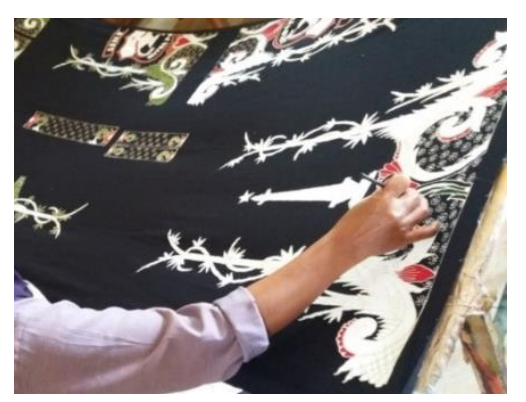

Gambar 6.

Proses Pewarnaan Batik Pring Sedapur (Dok. Riyanike Arista, 2016)

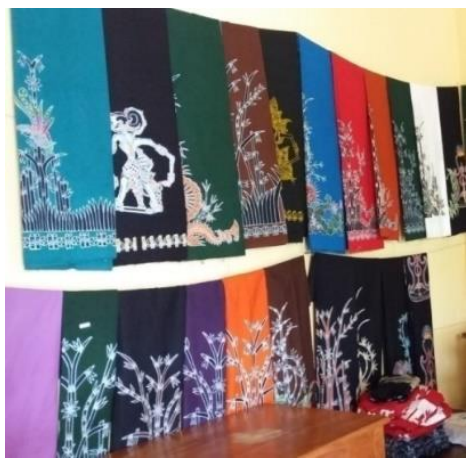

Gambar 7.

Batik Pring Sedapur

(Dok. Riyanike Arista, 2016)

\section{Latar Belakang Terciptanya Batik Ngawi}

Batik Ngawi pertama kali dipelopori oleh M.E. Budi Siwi Riyayanawati yang telah berjasa dalam menuangkan kreativitasnya dalam batik tulis yang menjadi ciri khas batik di Kabupaten Ngawi. Berawal dari putra kedua keluarga Alm. Budi Ristiono dan Budi Siwi Riyayanawati yang dianugerahi ketidakmampuan dalam mendengar sejak lahir yang bernama Widi Nugraha yang menyelesaikan sekolah SLB B yang setara dengan SMK dan mengambil kejuruan Tata Busana. Tuntutan kreativitas dalam mencari celah dan usaha untuk masa depan anaknya tersebut, Budi Siwi dan Widi Nugraha mencoba mempelajari proses pembuatan batik dan mengikuti kursus di Blitar selama 2 minggu pada tahun 2010. Setelah mengikuti kursus tersebut, Budi Siwi Hal| 134 memberanikan diri untuk memulai usaha kecil membuat batik tulis di rumah dan dibantu oleh Widi Nugraha. Sebelum mendesain batik, Budi Siwi aktif mencari informasi dan motif batik di internet. Mulai dari motif, pewarnaan dan teknik dalam membuat batik tulis. Dalam karya batik pertamanya (lihat gambar 7), rekan sejawat dari Alm. Budi Ristiono sebagai konsumen pertama dalam pembuatan batik Ngawi. Kain tersebut dijahit oleh anaknya, Widi Nugraha. Dalam perkembangannya satu tahun terakhir, batik Ngawi berjalan pelan dan dengan skala produksi yang masih sangat terbatas.

Semakin dikenalnya batik Ngawi karya Budi Siwi akhirnya membuat brand batik "Widi Nugraha" di tahun 2011. Mengambil nama putranya yang memiliki keahlian menjahit, mereka berkomitmen untuk menciptakan batik tulis dengan motif yang bernuansa asli Kabupaten Ngawi. Berbeda dengan motif batik sebelumnya yang sudah ada di Ngawi, yang umumnya bermotifkan klasik yang berkiblat pada kota Solo yang tidak mengangkat motif batik yang menjadi ciri khas Kabupaten Ngawi. Sehingga Budi Siwi mengakui jika beliaulah yang pertama mempelopori motif 


\section{Riyanike Arista}

batik asli Ngawi. Karena kewalahan produksi batik hanya dikerjakan dua orang, maka Budi Siwi mencari tenaga kerja untuk membantu dalam produksi seiring dengan adanya pesanan secara perseorangan yang mulai berdatangan. Karena para pekerja dari lingkungan masyarakat sekitar yang rata-rata sebagai ibu rumah tangga dan petani, maka Budi Siwi melatih satu per satu ibu-ibu dalam proses pembuatan batik, terutama dalam mencanting. Pada awalnya, Budi Siwi aktif mempromosikan batik tulis karyanya dari instansi ke instansi tetapi hanya menjadi bahan tertawaan karena motifnya yang masih sederhana. Dengan masih berbekal modal pribadi, hingga saat ini usaha Batik Tulis Widi Nugraha dapat berjalan dan mulai dikenal baik secara lokal maupun antar kabupaten melalui beberapa pameran batik. Skala produksi semakin meningkat dan usaha ini telah memiliki 5 karyawan tetap di bagian administrasi dan pewarnaan, 13 orang pekerja di bagian blat, dan sekitar 56 pecanting dari warga sekitar yang antusias dalam belajar membatik dan menekuni batik tulis sebagai mata pencaharian.

\section{Proses Kreatif Batik Bambu Ngawi}

Dalam menciptakan batik tulis Widi Nugraha, Budi Siwi terinspirasi dari kekayaan alam yang ada di Ngawi. Lebih dari seratus motif batik yang telah diciptakan, dan tidak lepas dari inspirasi yang didapatnya dari kekayaan alam dan latar belakang sosial masyarakat kabupaten Ngawi. Ngawi merupakan kabupaten di ujung barat Propinsi Jawa Timur dan berbatasan langsung dengan Propinsi Jawa Hal| 135 Tengah. Menurut sejarah, Ngawi berasal dari kata $N g$ dan $A w i$ dalam bahasa sansekerta berarti bambu.

Karena sejarah tersebut, maka Budi Siwi pertama kali terinspirasi membuat batik yang bermotif bambu. Motif tersebut ditemukan oleh beliau dari faktor lingkungan sekitar.

Latar belakang penciptaan motif batik bambu juga berpedoman pada logo Kabupaten Ngawi.

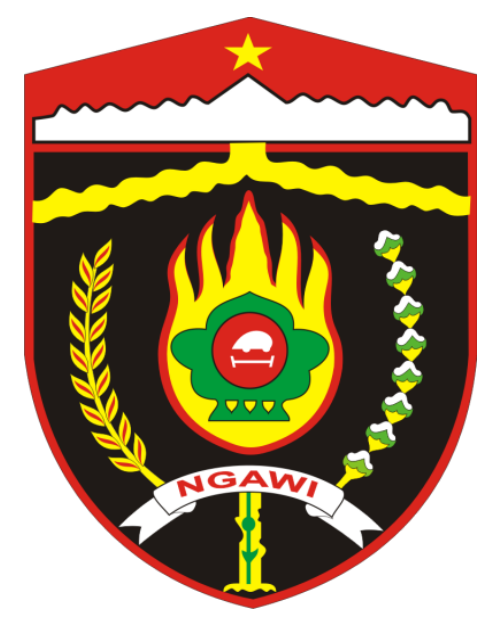

Gambar 9.

Logo Kabupaten Ngawi

(Sumber: www.ngawikab.go.id)

Pada logo Kabupaten Ngawi terdapat gambar bambu yang ukurannya pendek. Itulah sebabnya batik bambu di Ngawi mempunyai ciri khas yang motifnya tidak seperti ukuran bambu secara penuh 


\section{Riyanike Arista}

melainkan hanya potongan-potongan bambu.

Sebenarnya, motif batik bambu tidak menjadi motif yang diunggulkan, karena motif bambu pada batik sudah diciptakan dan diunggulkan di kota Magetan. Ngawi hanya mengunggulkan batik yang bermotifkan manusia purba. Walaupun demikian, batik Ngawi yang dibuat oleh Budi Siwi tetap menampilkan motif bambu sebagai isen-isen atau motif pendukung.

Dalam produksi batik Ngawi "Widi Nugraha", Budi Siwi yang menciptakan desain batik dari awal didirikan sampai sekarang. Sebelum menciptakan satu motif, Budi Siwi selalu menjalani riset terlebih dahulu. Riset dilakukan berdasarkan motif yang akan dibuat. Misalnya, dalam menciptakan motif bambu, beliau melakukan riset ke tempat yang banyak terdapat bambu di Ngawi. Jika ingin membuat motif manusia purba, beliau melakukan riset ke Museum Trinil. Museum Trinil merupakan satu-satunya museum yang terdapat manusia purba Pithecanthropus Erectus yang ditemukan di sekitar Museum Trinil, tepatnya dialiran sungai Bengawan Solo. Budi Siwi melakukan riset dengan mendatangi tempat tersebut, mempelajari sejarah asli sesuai dengan yang disampaikan oleh tour guide, dan mengamati bentuk tulang manusia purba Pithecanthropus Erectus. Dari riset tersebut, Budi Siwi membuat rancangan desain sesuai pengamatan yang pernah dilakukannya, namun desain batik tidak mirip dengan bentuk aslinya.

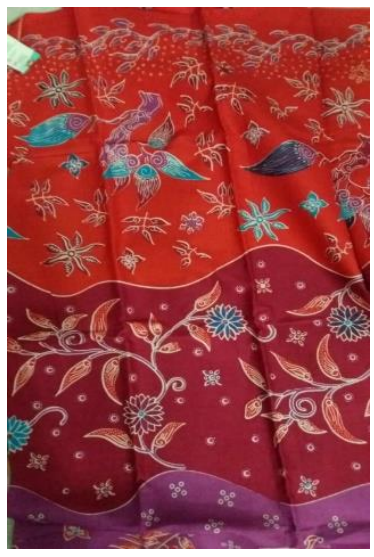

Hal| 136

Gambar 10.

Motif batik Sekar Jagat (Dok. Riyanike Arista, 2017)

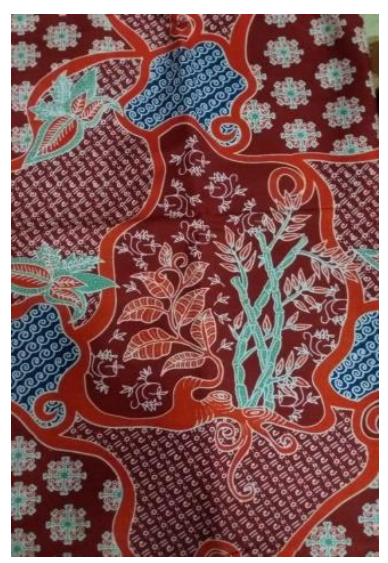

Gambar 11.

Motif batik Widi Nugraha

(Dok. Riyanike Arista, 2017)

Dahulu desainnya masih serupa dan mirip dengan bentuk aslinya, kalau sekarang sudah saya modifikasi bentuknya. Seperti tulang manusia purba, kemarin masih seperti tulang asli, sekarang seperti simbol-simbol yang melambangkan tulang manusia purba. Jika bentuk bambu, dahulu juga masih bambu asli, potonganpotonganbambu yang motifnya diulangulang, sekarang saya rangkai, bentuknya lebih luwes, dan saya kombinasikan dengan 


\section{Riyanike Arista}

potensi alam yang ada di Ngawi, misalnya jati dan daun teh. ${ }^{1}$

Riset dan desain dilakukan jika ada permintaan dan pesanan dari kelompok masyarakat atau pesanan dari luar kota. jika tidak ada pesanan, dan kondisi kesehatan serta emosional Budi Siwi sedang baik, baliau juga akan membuat desain tersebut. Dalam menciptakan desain batik, seperti desainer atau seniman lainnya, yakni pernah mengalami kesalahan. Desain tidak sesuai dengan permintaan konsumen. Dengan begitu, sebelum mendesain, beliau memahami permintaan konsumen seperti apa, selanjutnya jika batik sudah digambar, ditanyakan lagi ke konsumen apakah sesuai atau tidak. Jika sudah sesuai, batik akan di blat dan diproses ke tahap pencantingan dan pewarnaan.

\section{PENUTUP}

\section{Centra Batik Pring Sedapur} berpusat di Desa Sidomukti, Kecamatan Plaosan, Kabupaten Magetan. Batik Pring Sedapur pertama diciptakan oleh Tikno, yang pada saat itu menjabat sebagai Kepala Desa Sidomukti. Batik Magetan terkenal dengan sebutan batik Pring Sedapur. Batik ini terinspirasi dari tumbuhan bambu yang banyak tumbuh di Desa Sidomukti. Sehingga, bambu menjadi motif khas batik di Magetan. Sedangkan di kota Ngawi juga

\footnotetext{
${ }^{1}$ Wawancara Budi Siwi pada 11 Maret 2017 pukul 15.30 WIB
}

mempunyai batik yang menjadi ciri khas. Budi Siwi merupakan pelopor pertama pembuatan batik di Ngawi yang berpusat di Desa Munggut, Kecamatan Padas, Kabupaten Ngawi. Batik Ngawi mempunyai ciri khas motif bambu.

Motif bambu digunakan dalam motif batik karena kota Ngawi berasal dari kata $N g$ dan Awi yang berarti bambu. Terdapat banyak bambu yang tumbuh di berbagai wilayah di Kabupaten Ngawi. Dari kedua motif batik tersebut, mempunyai proses kreatif yang berbeda. Pencipta Batik Pring Sedapur melakukannya dengan mencari inspirasi di alam sekitar. Sedangkan dalam proses kreatif Batik Ngawi sebelum mendesain, Budi Siwi melakukan riset terlebih dahulu, memahami sejarah dan latar belakang potensi serta wisata yang menjadi kebanggaan kota Ngawi.

\section{KEPUSTAKAAN}

Anshori, Yusak dan Adi Kusrianto. 2011. Keeksotisan Batik Jawa Timur. Jakarta: Gramedia

Chandra, Julius. 1994. Kreativitas. Yogyakarta: Kanisius

Damajanti, Irma. 2006. Psikologi Seni. Bandung: Kiblat Buku Utama

Damajanti, Irma. 2014. Kajian Aspek Ketidaksadaran dalam Karya Seni Rupa Indonesia Periode 2000-2011. Vol. 01, No. 01, 17- 26.

Lisbijanto, Herry. 2013. Batik. Yogyakarta: Graha Ilmu

Moleong, Lexy J. 2007. Metode Penelitian Kualitatif. Bandung: Remaja Rosdakarya 


\section{Riyanike Arista}

Moleong, Lexy J. 2002. Metodologi Penelitian Kualitatif. Bandung: Remaja Rosdakarya

Musman, Asti dan Ambar B. Arini. 2011. Batik: Warisan Adiluhung Nusantara. Yogyakarta: G-Media

Prasetyo, Anindito. 2010. Batik. Yogyakarta: Pura Pustaka

Prawira, N. Ganda dan Dharsono. 2003. Pengantar Estetika dalam Seni Rupa. Bandung: Departemen Pendidikan Nasional

Setjoatmodjo, Pranjoto. 1988. Bacaan Pilihan Tentang Estetika. Jakarta: Departemen Pendidikan dan Kebudayaan

Sutopo, H.B. 2002. Metodologi Penelitian Kualitatif. Surakarta: UNS Press

Sutopo, H.B. 2006. Metodologi Penelitian Kualitatif. Surakarta: UNS Press

Sumardjo, Jakob. 2000. Filsafat Seni. Bandung: ITB

Wulandari, Ari. 2011. Batik Nusantara. Yogyakarta: ANDI

Sumber Lain:

1. Wawancara dengan narasumber M.E. Budi Siwi Riyayanawati

Alamat: Jalan Wahid Hasyim No.3, Karangasri, Ngawi

2. Wawancara dengan narasumber Johanes

Alamat: Jalan Wahid Hasyim No.3, Karangasri, Ngawi

3. Wawancara dengan narasumber Tikno

Alamat: Desa Sidomukti, RT. 10, RW. 02, Kecamatan Plaosan, Magetan 